\title{
Architecture and the Social Frameworks of Memory: A Postscript to Maurice Halbwachs' "Collective Memory"
}

\section{Abstract}

This paper offers a commentary on Maurice Halwachs' writings on "collective memory" in the years between 1925-1945. Architectural and urban spaces figure prominently in the work of the French sociologist since he maintains that memories survive in the longue durée only to the extent they are indexed into architectural places, and mapped into an urban and historical topography. This comes with a caveat: in his pioneering study of "collective memory," La topographie légendaire des Évangiles en Terre Sainte: Étude de mémoire collective, Halbwachs highlights the discrepancy between the archaeological record preserved in material culture-for example ancient ruins and monuments-and the living memory of a religious community. Likewise, in his study of working classes, Halbwachs' neologism, "collective memory" is defined as a deliberately unstable, and socially constructed category.

The provisional and fluid definition that Halbwachs assigned to "collective memory" offers an insight into our present predicament. In the last decades, the ability of architecture, urban design, and
Keywords: Halbwachs, Maurice (1877-1945), Collective Memory, Social Frameworks of Memory, Sites of Memory, Architecture, Monuments, Memorials and Social Reception, Les Cadres sociaux de la mémoire (1925 book), La topographie légendaire des Évangiles en Terre Sainte: etude de mémoire collective (1941 book)

*Prof. Dr., Department of Art, Architecture \& Art History, University of San Diego, USA.

E-mail: cbilsel@sandiego.edu 
architectural conservation in framing and preserving a stable and unified cultural heritage has been profoundly challenged. This paper makes the case for moving away from merely technical inquiries that understand architecture and places as "sites of memory" to a new direction that builds upon Halbwachs' social frameworks of memory. It is thanks to Halbwach's pioneering, if incomplete, work on "collective memory" that we may understand how the emerging and open-ended social formations transform architecture and urban spaces.

I.

What is "the memory of place," an idea frequently evoked in architecture, urban planning and architectural conservation: a concept so ubiquitous and vague that it can inform disciplinary practices as distinct as new urban design in historical settings, adaptive reuse in architectural restorations, the installation of war memorials/counter-monuments, or even the interpretation and management of archaeological sites? Although it is difficult to single out any method, either interpretive or tactical, that could encompass "memory" in all the disciplines that are represented in this conference, a broad connection emerges in the way many contributions readily assign the experts the role of the custodian of public memory. Often architects, urban planners or architectural conservation specialists act to serve public interest, broadly defined. But who exactly is the public for whom we safeguard memory? Whose memory is "the memory of place"? As architects, planners and conservationists, we are too quick to equate memory registered in architectural and urban places with identity and heritage. But public memory also consists of trauma, social discord, political oppression and resistance. Recent experience has shown that the unthinking uses of architecture

1 Halbwach's posthumously published book was translated into English as The Collective Memory in 1980 with an introduction by Mary Douglas (New York: Harper and Row, 1980). In 1992 Lewis A. Coser translated selections from Halbwachs' 1925 book Les Cadres sociaux de la mémoire [The Social Frameworks of Memory], and the conclusion of the 1941 book La Topographie légendaire des Évangiles en Terre Sainte [The Legendary Topography of the Gospels in the Holy Land] in the volume On Collective Memory (Chicago: The University of Chicago Press, 1992), which remains the most comprehensive translation of Halbwachs' work. and architectural restoration for cultural heritage reconstruction, or to "reconstruct history," may amount to a top-down imposition of amnesia upon the people, destroying the social fabric of memory. For, memories are socially constructed and diverse, and are linked to architectural and urban places in unexpected ways.

I wish to refocus our attention to a topic that is highly pertinent to our subject, the relation of architecture to what the French sociologist Maurice Halbwachs called "the social frameworks of memory" (les cadres sociaux de la mémoire). Between the 1920s and 1945, a time marked by great social and political upheavals, Halbwachs developed the theory of "collective memory."

Although Halbwachs's work has attracted significant interest among the sociologists and historians over the last decades, he is not a widely read author in architectural history and conservation studies. This is in part due to the fact that many of Halbwachs' key works are unavailable in English ${ }^{1}$ (Olick, Vinitzky-Serouiss, \& 
Levy, 2011). The English reading architecture audiences have been introduced to Halbwachs' work either through secondary sources or anthologies. Aldo Rossi's The Architecture of the City, for one, includes numerous references to Halbwachs' work on urban sociology and collective memory, duly acknowledging Rossi's intellectual debt to the French sociologist (Rossi, 1982). The French historian Pierre Nora and his colleagues' frequently cited thesis, which counterposes les lieux de mémoire [the sites of memory / the sites of national heritage] against living/communal memory, is undoubtedly indebted to Halbwach's theory of collective memory (Nora, 1998). Finally, M. Christine Boyer's The City of Collective Memory introduced Halbwachs's work to an architecture audience in 1994 (Boyer, 1994). All these, however, remain exceptions and Halbwachs' work has rarely been central for architects, planners and conservationists outside continental Europe, despite his methodological innovation, as I shall return in due order.

Maurice Halbwachs' intellectual biography comes across as an unlikely combination of distinct scholarly traditions. He started his journey as a student of Henri Bergson at the Lycée Henri IV in Paris. You may recall that Bergson, the anti-positivist philosopher, is one of the most influential thinkers of the early $20^{\text {th }}$ century, whose writings shaped the idea of "experience" and "memory" in France and in Europe at large. Beginning 1889, with the publication of his first major book, Essai sur les données immédiates de la conscience, Bergson offered a critique of the positivist psychology of the nineteenth century. At issue was the psychologists' assumption that they may accurately register and measure the movements of animal and human subjects, as well as human consciousness as a function of time. Bergson famously rejected the scientifically measured, objective time as a mere abstraction. To the scientific notion of abstract, homogeneous and empty time, Bergson opposed an ontological time, "la durée" or duration, which according to Bergson, is intrinsic to the lifeprocess and the "élan vital" of all living beings ${ }^{2}$ (Bergson, 1889).

It is no small wonder that Halbwachs, who had been introduced to philosophy under Bergson at an early age, dedicated the following decade to rejecting the subjectivist philosophy of his former master. After a brief journey in Berlin, Halbwachs joined in Paris to what was practically a rival camp, the school of scientific sociology of Emile Durkheim."(Douglas, 1980). By 1913 when Halbwachs published his doctoral dissertation: La classe ouvrière et les niveaux de vie. Recherche sur des besoins dans les sociétés industrielles contemporaines, his conversion to Durkheimian sociology is complete. By then Halbwachs had become a committed socialist: his conversion from spiritual philosophy to
2 See also Henri Bergson, Matière et Mémoire (1896). Fifth edition of the PUF (Paris: PUF, 1997); and Henri Bergson. L'Évolution créatrice (Paris: Félix Alcan, 1907). English translation: Creative Evolution. Arthur Mitchel, transl. (1911) (New York: Random House, 1944). 
3 See also John E. Craig, Scholarship and Nation Building: The Universities of Strasbourg and Alsatian Society, 1870-1939, (Chicago: The University of Chicago, 1984). scientific sociology should be understood in the context of his participation in the social movements and the anti-fascist struggles of 1920-1945 (Iogna-Prat, 2011).

Another translation occurs in Halbwach's work between history and sociology in the experimental and interdisciplinary academic environment of Strasbourg in the 1920s, where he taught as a professor of sociology. After recapturing the province of Alsace from Germany in 1918, the French government took action to make the University of Strasbourg French. The German professors were summarily fired and replaced with an unusually young generation of French academics ${ }^{3}$ (Craig, 1979). Hailing from a Catholic Alsatian family, which had its unquestionable allegiance to the French Republic (Iogna-Prat, 2011). Halbwachs nevertheless was one of the first to reach out to his German colleagues. He introduced the pioneers of German sociology, such as Max Weber, to France.

In 1929 Halbwach's colleagues in Strasbourg, the historians March Bloch and Lucien Febvre initiated the groundbreaking Annales school, organized around the journal of the same name. Although not a historian by training, Halbwachs agreed to serve on the new journal's editorial board, in addition to contributing numerous articles, and helped Bloch and Febvre devise a new historiography informed by social sciences (Hutton, 1993).

It should not come as a surprise that Halbwachs wrote his first book on memory Les Cadres sociaux de la mémoire in 1925 in Strasbourg. The book is as much a history of European social classes, in conversation with Weber, as a rejection of Sigmund Freud's theory of the unconscious (Halbwachs, 1925). More specifically Halbwachs rejected Freud's notion that memories are kept in the unconscious psyche. While Halbwachs acknowledges that each individual retains a mental image of the past events, these representations are fleeting. The images of the past can be structured into lasting memories only to the extent they are contextualized by the social group to which the individual belongs, be it a family, a social class, or a religious community. Collective memory thus transcends simple reminiscences of the past, and encompasses tastes, values, and social mores of a community (Hutton, 1993). By providing a brief history of the social mores of the European feudal classes, Halbwachs shows in this book how the representations of family heritage and social class allegiances intersected, and how precarious and unstable these representations can be. Collective memories are not only localized and indexed to a social group, but need to be kept alive by ritual practices, traditions and repetitions (Halbwachs, 1925). 
Published in 1941 in Paris, La Topographie légendaire des Évangiles en Terre Sainte: Étude de mémoire collective [The Legendary Topography of the Gospels in the Holy Land] is the most architectural of Halbwachs' books (Halbwachs, 1941). Having traveled to Palestine twice in the late 1920s and again in 1939, and reviewed the historical accounts of travelers and pilgrims, and architectural shrines, Halbwachs wrote a book about the commemorative landscape of the Holy Land (IognaPrat, 2011). He contends that none of the shrines or relics that remain in historical Palestine dates back to the day of Jesus of the Gospel, and were instead introduced to the land by the Christian Church starting the $4^{\text {th }}$ century. This was a process that was interrupted by the Muslim conquests of the $7^{\text {th }}$ century, and resumed after the Crusades of late Middle Ages. Halbwachs maintained that the collective memory of the sacred land changes from one generation to another according to the social and historical transformations of each historical present. In order to demonstrate his thesis, Halbwachs studied the archeological record and the travellers' accounts about the Christian monuments in Palestine, together with the "legendary topography" of the Holy Land as maintained in the collective memory of the Christian communities, only to conclude that there was little connection between the two. The conclusion here is radical and fascinating: as Patrick Hutton has observed, according to Halbwachs, the construction of the Holy Land in the Christian consciousness was a form of "colonization" of memory, a process that imposed the European version of the religion upon the indigenous peoples of Palestine, Christians, Jews, and later Muslims alike (Hutton, 1993).

We should note here that Halbwachs wrote La Topographie légendaire more than three decades before Edward Said's renowned book Orientalism (Said, 1978). Yet his critique is far more sweeping. For Halbwachs, as Said, the East or the Holy Land is not merely there. It is a social construction. But Halbwachs is not limiting himself to analyzing the Western European discourse in a given present. He is far more ambitious: he wants to know how the shifts in collective memory have transformed in the longue durée the religious tradition. The architecture, urban landscapes, and historical topography of Palestine provided Halbwachs with a fascinating case.

According to Halbwachs, the collective memory is in constant flux in the consciousness of a group. Yet when an event experienced by the group is memorialized into a monument, collective memory is fixed in architecture. His study, in other words, both revolutionizes the sociology of knowledge, and yet, paradoxically, 
rests on the positivist assumption that architectural monuments of the past communicate only the original intent of commemoration. Halbwachs believes that architectural monuments help the ruling power-a church, a sovereign family, or a state-control or delay the inevitable shifts in the collective memory of the faithful.

In March 1945 Maurice Halbwachs, the man who introduced "collective memory" to the world literature, died in Buchenwald Nazi concentration camp. He was arrested and deported to the concentration camp after protesting against injustice of the Nazi occupation. Years later, in 1987, another French sociologist, Pierre Bourdieu laments the assassination of Halbwachs. "There is no hierarchy in murder," Bourdieu writes,

"Yet, one cannot help but plunge into ethical despair about the assassination of a defender of the universal, a man who dedicated all his intelligence and conviction to create the conditions for understanding and tolerance among the peoples separated by history."(Bourdieu, 1987).

II.

The provisional and fluid definition that Halbwachs assigned to "collective memory" offers an insight into our present predicament. In the last decades, the ability of architecture, urban design, and architectural conservation in framing and preserving a stable and unified cultural heritage has been profoundly challenged. During the ethnic strife and ensuing civil wars of Bosnia Herzegovina and Kosovo in the 1990s, the battle was fought, in no small part, over cultural and architectural heritage. Communal violence targeted not only civilian populations, but also sought to erase all traces of the other's architectural heritage: Kosovar mosques have been the targets of systematic destruction (Herscher \& Riedlmayer, 2000). A formerly multi-ethnic nation's public memory was Balkanized into shattered and irreconcilable collective memories.

The urban revolts that have arisen around the world in 2010-13, starting with the self-immolation of a Tunusian street vendor, the Egyptian Revolution in the Tahrir Square, the occupation of prominent public spaces during the Indignados and the Occupy Wall Street in Spain and the United States, as well as São Paolo's public transportation riots, and the Gezi Resistance have further eroded citizens' trust in the ability of monumental architecture in representing a pluralistic and yet unifying memory in public spaces. A "long Arab Winter" followed the hopeful beginning of "the Arab Spring": either the state apparatus failed, or new 
authoritarian regimes are consolidated (Mitchel, 2012). Just as social upheaval, oppression and resistance came to define more of the urban experience in the Middle East, new forms of commemoration such as performative reenactments of events in public spaces or new media have replaced architecture as anchors of collective memory. By Balkanization of memory, I refer to a current situation where different social groups not only remember recent social events differently, but also prove shockingly oblivious to the suffering of the others.

I argue that Halbwachs' theory of collective memory is more relevant today than ever methodologically, due to the current fragmentation of public memory, and the crisis of architecture's ability to commemorate a collective past. By the time of his death, Halbwachs was working on a new book on collective memory, which was posthumously published.

Whereas his earlier book, Les cadres sociaux, argues that an individual's allegiance to a family, a religious community, or a social class is the determining factor in shaping his or her acquisition of social memory, his late work on memorycompiled as La mémoire collective-significantly revises his earlier position. As Gérard Namer has recently shown, Halbwachs' argues in his late work that an individual may have multiple allegiances to competing social frameworks, and thus to competing collective memories ${ }^{4}$ (Déchaux, 1998). This might give us hope. It means that memories are not restricted to a closed community. Halbwach's position amount to a cosmopolitan theory: the liberty of the individual to choose plays a role in his or her adherence to a living collective memory.

\section{Acknowledgement}

In May 2017 I traveled to Konya, Turkey, for an invited speech at the third International Congress of Architecture held at Selçuk University. The theme of the conference, communicated in an open call for papers, was "the memory of place in architecture and planning." The following paper is my response to this invitation. It is as much a commentary on Maurice Halwachs' writings on "collective memory" in the years between 1925-1945, as my own response to the crises in public memory in our own present.

\section{REFERENCES}

Bergson, H. (1889). Essai sur les données immédiates de la conscience. Paris: Félix Alcan

Bourdieu, P. (1987). L'assassinat de Maurice Halbwachs. Visages de la Resistance, 16, 166.

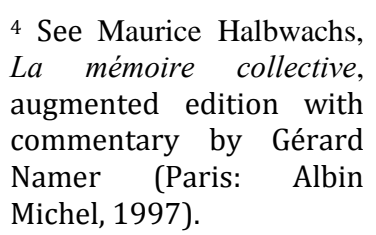
augmented edition with commentary by Gérard Namer (Paris: Albin Michel, 1997). 
Boyer, M. C. (1994). The City of Collective Memory: Its Historical Imagery and Architectural Entertainments. Cambridge Massachusetts: MIT Press.

Craig, J. E. (1979). Maurice Halbwachs à Strasbourg. Revue française de sociologie, 20(1), 272-292.

Déchaux, J.-H. (1998). Review of Maurice Halbwachs, La mémoire collective. Revue française de sociologie, 39(3), 624-625.

Douglas, M. (1980). Introduction: Maurice Halbwachs (18771945) The Collective Memory (pp. 4-6). New York: Harper\&Row.

Halbwachs, M. (1925). Les cadres sociaux de la mémoire. Paris: Félix Alcan, 1925.

Halbwachs, M. (1941). La Topographie légendaire des Évangiles en Terre Sainte: Étude de mémoire collective Paris: Presses Universitaires de France.

Herscher, A., \& Riedlmayer, A. (2000). Monument and crime: the destruction of historic architecture in Kosovo. Grey Room, 1(Autumn), 108-122.

Hutton, P. H. (1993). History as an Art of Memory Hanover, Vermont: University of Vermont.

Iogna-Prat, D. (2011). Maurice Halbwachs ou la mnémotopie: 'Textes topographiques' et inscription spatiale de la mémoire. Annales. Histoire, Sciences Sociales, 66e Année(3), 821-838.

Mitchel, W. J. T. (2012). Image, Space, Revolution: The Arts of Occupation. Critical Inquiry, 39(1), 32.

Nora, P. (1998). Realms of Memory: Rethinking the French Past (D. L. Kritzman Ed. 3 volumes). USA: Columbia University Press.

Olick, J. K., Vinitzky-Serouiss, V., \& Levy, D. (2011). The Collective Memory Reader. Oxford: Oxford University Press.

Rossi, A. (1982). The Architecture of the City Cambridge Massachusetts: The MIT Press.

Said, E. (1978). Orientalism. New York: Vintage.

\section{Resume}

Can Bilsel is Professor of Architecture at the University of San Diego. His research bridges the fields of the history and theory of modern architecture, urbanism, and housing, the history of archaeology and museum reconstructions, the history of architectural conservation, cultural theory, and postcolonial studies. He is the author of Antiquity on Display: Regimes of the Authentic in Berlin's Pergamon Museum, published in 2012 by the Oxford University Press. Bilsel is currently co-editing, with Juliana Maxim, Architecture and the Housing Question a book that will feature the research of 15 authors from around the world. Bilsel received his Ph.D. in Architecture at Princeton University, a Master of Science degree from MIT School of Architecture, and a professional Bachelor of Architecture from METU (ODTÜ) in Turkey. For nearly a decade Bilsel was the Chair of the Department of Art, Architecture and Art History, and the 
Architecture and the Social Frameworks of Memory: A Postscript to Maurice Halbwachs' "Collective Memory"

founding Director of the University of San Diego's Architecture Program. In addition to his tenured professorship at the University of San Diego, Bilsel teaches seminars in the PhD and Masters programs in Architecture and Urban Design at UCLA. 